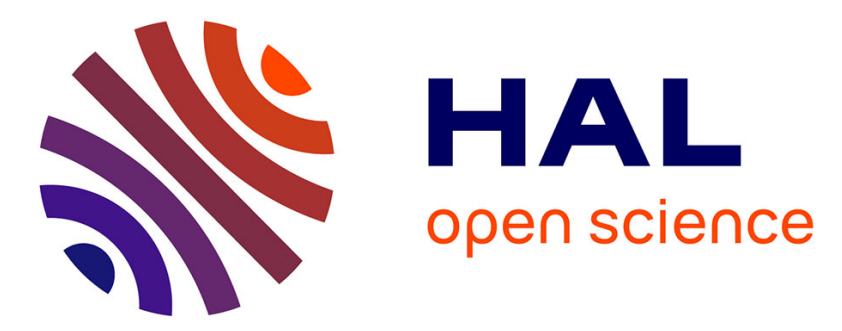

\title{
Optimization of concrete mix design to account for strength and hydration heat in massive concrete structures
}

Agathe Bourchy, Laury Barnes, Laetitia Bessette, Florian Chalencon, Aurélien Joron, Jean Michel Torrenti

\section{To cite this version:}

Agathe Bourchy, Laury Barnes, Laetitia Bessette, Florian Chalencon, Aurélien Joron, et al.. Optimization of concrete mix design to account for strength and hydration heat in massive concrete structures. Cement and Concrete Composites, 2019, 103, pp. 233-241. 10.1016/j.cemconcomp.2019.05.005 . hal-02466837

\section{HAL Id: hal-02466837 https://hal.science/hal-02466837}

Submitted on 4 Feb 2020

HAL is a multi-disciplinary open access archive for the deposit and dissemination of scientific research documents, whether they are published or not. The documents may come from teaching and research institutions in France or abroad, or from public or private research centers.
L'archive ouverte pluridisciplinaire HAL, est destinée au dépôt et à la diffusion de documents scientifiques de niveau recherche, publiés ou non, émanant des établissements d'enseignement et de recherche français ou étrangers, des laboratoires publics ou privés. 
1 Optimization of concrete mix design to account for strength and hydration heat in massive

2 concrete structures.

3

4 Agathe Bourchy ${ }^{1}$, Laury Barnes ${ }^{2}$, Laetitia Bessette ${ }^{2}$, Florian Chalencon $^{3}$, Aurélien Joron ${ }^{3}$ and $5 \quad$ Jean Michel Torrenti ${ }^{*}$

6

$7 \quad{ }^{1}$ IFSTTAR, Materials and Structures Department, 14-20 boulevard Newton, 77420 Champ-sur-

8 Marne, France

$9 \quad{ }^{2}$ Vicat SA, 4 rue Aristide Bergès, 38080 L'Isle d'Abeau, France

$10{ }^{3}$ Sigma Béton SA, 4 rue Aristide Bergès, 38080 L'Isle d'Abeau, France

11

$12 *$ Corresponding author

13 Tel.: +331.81 .66 .84 .40$

14 email: jean-michel.torrenti@ifsttar.fr 


\section{ABSTRACT}

16 In the case of massive concrete structures, the heat generated by cement hydration may cause

17 cracking due to thermal strains. The mix design of the concrete used for such structures has to

18 take account of mechanical properties and generated temperatures. Using experimental design

19 principles, the hydration heat and the development of compressive strength are measured in order

20 to determine how the composition of concrete and the presence of SCM influence the

21 characteristics of concrete and to create a mix design protocol. This protocol can help to

22 determine which mix design minimizes the hydration temperature for a given compressive

23 strength.

24 KEYWORDS: concrete, formulation, supplementary cementitious materials, hydration heat, 25 compressive strength. 


\section{INTRODUCTION}

27 In massive structures, the exothermy of the hydration reactions of cement and the thermo-hydro28 mechanical behavior of early age concrete can lead, if strains are restrained, to the development

29 of compressive and tensile stresses. If the tensile stresses exceed the tensile strength, cracking

30 may occur, threatening the durability of the concrete. In order to prevent the risk of cracking as

31 well as that of Delayed Ettringite Formation (DEF), sulfate resisting cement and the use of

32 additions are recommended [1]. Mineral additions such as limestone, slag or fly ash can also be

33 added to concrete to decrease the exothermy of hydration reactions and, in the case of slag and

34 fly ash, protect against DEF.

35 The aim of this research is to obtain a tool which optimizes concrete mix design while respecting 36 classical specifications such as the compressive strength after 28 days and minimizing the 37 temperature rise in massive structures. To do this, the impact of several parameters of cement 38 (composition and fineness) and of concrete (type and percentage of additions, W/B ratio, 39 chemical admixtures) on the rheology, hydration heat and mechanical strength of concrete have 40 been studied by means of an experimental design. The influence of the different factors is 41 analyzed and a concrete mix tool is proposed. Finally, this tool is applied to the case of massive 42 concrete structures.

\section{CURRENT STATE OF KNOWLEDGE}

45 The hydration reaction of cement is exothermic and the heat that is produced can lead to DEF or 46 cracking under particular conditions and especially in massive concrete structures [2,3]. Usually, 47 mix design - cement, additions, water-to-binder ratio, chemical admixtures - is optimized with 48 reference to workability, setting time, compressive strength at early or later age (Bolomey 
49 equation for compressive strength after 28 days [4]) or the hydration heat [5,6] and in order to

50 limit the risk of cracking. Depending on the notional size of the concrete structure in question, it

51 is important to optimize the concrete mix design, the hydration kinetic and the total heat release

52 which impact temperature changes in the structure.

53 Firstly, it is possible to optimize the granular skeleton in order to minimize the quantity of cement

54 paste as recommended in the standard EN 206 [7] with classical methods such as the ACI method

55 [8] or the de Larrard [5] method which take into account the size and form of the particles. The

56 standard EN 12620 gives the characteristics of aggregates which can be employed in concrete [9].

57 Then, when the granular skeleton has been optimized, it is possible to optimize the composition

58 of the paste. This involves selecting the type of cement with respect to durability and such

59 properties as carbonation, the alkali reaction or DEF: special attention is paid to the amount of

60 sulfate in the cement provided by alkaline sulfates or a setting regulator. For Byfors [10] and

61 Minard [11], coupling occurs between the anhydrous phases and for Lerch and Bogue, it is

62 possible to reduce hydration heat by reducing the quantity of highly reactive phases such as $\mathrm{C}_{3} \mathrm{~A}$

63 and $\mathrm{C}_{3} \mathrm{~S}$ [12]. Furthermore, the more fine the cement, the faster the hydration reactions which can

64 increase the rate at which hydration heat is released [13-15].

65 The heat of hydration can be limited when mineral additions - reactive or not - are used in the

66 cement as recommended in the standard EN 197-1 [16] or by several authors [17,18], but they

67 may also be used in the concrete as described in standard EN 206 [7]. Mineral additions in

68 cementitious materials change their properties over time [19]. Even if these modifications can be

69 related to the characteristics of additions (type of fly ash, slag fineness...), several general points

70 are accepted. During hydration, mineral additions interact with hydrates and modify heat release

71 and mechanical properties. It is possible to explain this on the basis of several phenomena: a 4 
72 granular effect which affects the material in its fresh state and its rheology and a physico-

73 chemical effect which affects the hydration and setting of the material.

74 The granular or filler effect is mainly due to fine and ultra-fine particles of materials such as

75 limestone [20-23] or silica fume [24]. For Villagran-Zaccardi, et al. [25], Lothenbach, et al. [26]

76 and Schöler, et al. [27], the fineness of mineral additions affects the hydration kinetic, especially

77 the hydration of aluminates due to a filler effect: the impact is faster for limestone and slower for

78 slag [28,29] and fly ash [30]. These particles position themselves between the cement particles

79 [31]. This effect can have a beneficial or an adverse impact on material properties in the fresh

80 state - i.e. their slump and rheology. According to Ramachandran, et al., for similar specific

81 surfaces, fly ash increases fluidity thanks to its spherical surface [32] whereas slag increases

82 viscosity due to its irregular surface which decreases the granular skeleton [33]. Their specific

83 surface areas are respectively equal to $3,800 \mathrm{~cm}^{2} \cdot \mathrm{g}^{-1}$ and $4,200 \mathrm{~cm}^{2} \cdot \mathrm{g}^{-1}$ for fly ash and slag. In the

84 case of silica fume, due to its very high specific surface $\left(150,000\right.$ to $\left.200,000 \mathrm{~cm}^{2} \cdot \mathrm{g}^{-1}\right)$ the use of a

85 superplasticizer is essential in order to obtain an acceptable level of fluidity [34]. The

86 physicochemical effect - nucleation sites and modification of hydrate morphology and secondary

87 hydration reactions - affects the interactions between additions, anhydrous and hydrates and so

88 modifies the hydration process $[19,28]$. Generally, the presence of additions decreases the early

89 age heat of hydration [26]. For example, limestone, being a non-reactive addition, decreases the

90 hydration heat [28] but gives higher early age compressive strengths than Portland cement thanks

91 to its role as a nucleation site [23,35], and it also improves cement hydration [26,36]. Lawrence,

92 et al. have shown that limestone in cement increases early age mechanical strength because of its

93 reactions with the $\mathrm{C}_{3} \mathrm{~A}$ and $\mathrm{C}_{4} \mathrm{AF}$ phases (formation of aluminates and carboaluminates) but later

94 its impact becomes marginal $[37,38]$. As a result of their low early age reactivity $[29,30,39]$ and 
95 the increase in the length of the dormant period [40,41], slag and fly ash produce low hydration

96 heat with time. The compressive strength is lower at early age but similar to or higher than

97 compressive strength after 28 days for concretes without slag and fly ash considering an equal

98 binder content $[30,42]$. However, for Berodier, an increase in the percentage of slag increases the

99 hydration heat released up to a maximum value when there is not enough cement to activate the

100 slag [28]. For Schindler and Folliard, a higher percentage of fly ash in concrete does not retard

101 hydration and the production of hydration heat while a higher percentage of slag retards the

102 hydration of cement and decreases the hydration heat [43]. In contrast, silica fume, which is very

103 reactive and exothermic, gives a higher compressive strength from early age [39]. Moreover, the

104 reactions are sensitive to temperature [44-46], especially those involving slag [47] and fly ash

105 which have a high activation energy (around $65 \mathrm{~kJ} . \mathrm{K}^{-1}$ ) [48]. Additions are taken into account in

106 concrete mix design via the notion of equivalent binder which corresponds to the sum of the

107 quantity of cement and the quantity of addition multiplied by the activity coefficient of the

108 addition. It would be possible to estimate mechanical strengths using expressions which include

109 the equivalent binder. For instance, in the Bolomey formula, see equation (1), the equivalent

110 binder is calculated with the activity coefficient $\mathrm{k}$ considered as a constant. But according to Cyr,

111 et al. and Khokhar, et al., this coefficient varies according to the type of cement (C) and addition

112 (A) because of the interaction between them, but also according to the quantity of addition and

113 the age of concrete $[49,50]$.

$$
R_{c}=G \cdot R_{C_{-} \text {cement } \text { iso }_{-}} \cdot\left(\frac{C+k \cdot A}{W}-0.5\right)
$$


114 where $\mathrm{G}$ is the granular coefficient which depends on the quality and maximum size of the

115 granular material, $R_{C_{-} \text {cement_iso }}$ is the compressive strength of the cement after 28 days $(\mathrm{MPa}), \mathrm{C}$,

116 A and $\mathrm{W}$ the quantity of cement, addition and water $(\mathrm{kg})$.

$117 \mathrm{Hu}$ et al. show that when the water-to-binder ratio decreases, hydration reactions are faster and 118 the hydration heat increases. If the water-to-binder ratio is higher than 0.7 , the reactive materials

119 are diluted which leads to fewer hydration reactions and therefore lower hydration heat [51]. For

120 Torrenti and Benboudjema, for a cement paste, the higher the water-to-binder ratio, the longer it

121 takes for hydration to begin and the first mechanical properties to appear [52]. For Stefan, in the

122 case of mortar or concrete, the granular skeleton also plays a role in the development of the

123 mechanical characteristics at very early age [53]. On the contrary, for Hewlett, the water-to-

124 binder ratio needs to be higher for fine cement to obtain good hydration and fresh state properties

125 as well as during hardening [54]. For Kadri and Duval, the water-to-binder ratio can be optimized

126 in order to obtain low hydration heat for concrete containing silica fume [55] or, according to

127 Hani, et al. [56], in order to obtain better mechanical properties.

128 Mineral additions impact the water demand and the fluidity of concrete, especially when recycled

129 aggregates are used [57]. In order to regulate these effects, chemical admixtures can be used to

130 defloculate fine particles and free water between these particles [58]. The use of chemical

131 admixtures makes it possible to decrease the water-to-binder ratio and thus increase the

132 mechanical strength by improving the microstructure [59]. For Huang, et al., in the case of higher

133 percentages of entrained air, chemical admixtures are more effective [60]. For Mardani-

134 Aghbaghou, et al., the chemical admixture needs to be chosen on the basis of the type of sulfates

135 present in cement, i.e. anhydrite or gypsum, because of the difference in their reactivity in the 
136 presence of superplasticizers [61]. Moreover, the standard EN 934-2 states that a chemical

137 admixture can only be used in concrete if the $\mathrm{SO}_{3}$ content is lower than $2 \%$ [62].

138 After analysis of the literature, we decided to study the impact of the type and quantity of cement,

139 the type and quantity of additions, the water-to-binder ratio and the quantity of chemical

140 admixture on the early age thermomechanical properties of concrete, and in particular to perform

141 experimental design in order to minimize heat release for a given strength. To do this, three

142 cements and three additions were selected in order to compare their effect on hydration heat and

143 mechanical properties.

\section{MATERIALS AND METHODS}

146 The materials and method are presented below. The Bolomey formula (eq. (1)) is used in the 147 experimental design.

\subsection{Materials tested}

$150 \quad 3.1 .1 \quad$ Selected cements

151 The three cements were selected on the basis of their hydration heat and their compressive 152 strengths. They were produced in a pilot scale ball mill, and their composition varied from CEM I 153 (95 to 100 percent of cement), CEMII/A-LL (80 to 94 percent of cement and 6 to 20 percent of 154 limestone) and CEM II/B-LL (65 to 79 percent of cement and 21 to 35 percent of limestone).

155 The first selected cement, denoted by $\mathrm{C} 1$, was equivalent to a CEM II/B-LL and contained $35 \%$ 156 of limestone, $5.85 \%$ of anhydrite and had a median particle diameter of $12 \mu \mathrm{m}$. The second 157 cement is denoted by $\mathrm{C} 2$ and was equivalent to a CEM II/A-LL. It contained $20 \%$ of limestone, $1585.85 \%$ of anhydrite and had a median diameter of $12 \mu \mathrm{m}$. Finally, the third cement (C3) 
159 contained only $5 \%$ of limestone but $7.85 \%$ of anhydrite and had a median diameter of $9 \mu \mathrm{m}$.

160 This cement corresponded to a CEM I. Table 1 presents the characteristics of the selected 161 cements.

163 Table 1. Characteristics of selected cements.

\begin{tabular}{|c|c|c|c|}
\cline { 2 - 4 } \multicolumn{1}{c|}{} & $\mathrm{C} 1$ & $\mathrm{C} 2$ & $\mathrm{C} 3$ \\
\hline $\mathrm{D}_{50}(\mu \mathrm{m})$ & 11.2 & 11.4 & 12.0 \\
\hline Blaine surface area $\left(\mathrm{cm}^{2} \cdot \mathrm{g}^{-1}\right)$ & 5300 & 4450 & 4270 \\
\hline Density $\left(\mathrm{g} . \mathrm{cm}^{-3}\right)$ & 3.00 & 3.06 & 3.13 \\
\hline Water demand $(\%)$ & 32.0 & 34.0 & 37.0 \\
\hline Beginning of setting time (min) & 185 & 170 & 240 \\
\hline End of setting time (min) & 260 & 225 & 310 \\
\hline
\end{tabular}

165 The water demand of our cements was measured according to the standard EN 196-3 [63] and is

166 higher than that usually obtained for cements. This is due to the way our cements were produced,

167 with a pilot ball mill rather than an industrial facility. This affects the rheology of the concretes.

168 Table 2 shows the hydration heat and mechanical characteristics of mortars made from cement

169 measured as described in the standards EN 196-9 [64] for hydration heat and EN 196-1 for

170 compressive strength [65]. The compressive strengths after 28 days varied from 40 to $60 \mathrm{MPa}$.

171 The hydration heat measurements were corrected using the method proposed in EN 196-9 [64].

172 The less limestone a cement contains, the higher is its hydration heat after $41 \mathrm{~h}$, but with time the

173 cement becomes less reactive and less hydration heat is produced. After 5 days, cements $\mathrm{C} 1$ and

174 C2, which respectively contained 35 and $20 \%$ of limestone, produced the same hydration heat

175 (allowing for uncertainty) of $20{\mathrm{~J} . \mathrm{g}^{-1}}$ while cement C3, with a limestone content of only $5 \%$, was

176 still reactive and produced $100{\mathrm{~J} . \mathrm{g}^{-1}}^{-1}$ more than the other two after 7 days. 
177 Table 2. Thermal (Langavant hydration heats $\mathrm{Q}_{41}, \mathrm{Q}_{120}$ and $\mathrm{Q}_{168}$ measured respectively after 41, 178120 and 168 hours) and mechanical characteristics obtained for mortars made from the three 179 selected cements.

\begin{tabular}{|c|c|c|c|}
\cline { 2 - 4 } \multicolumn{1}{c|}{} & $\mathrm{C} 1$ & $\mathrm{C} 2$ & $\mathrm{C} 3$ \\
\hline $\mathrm{Q}_{41}\left(\mathrm{~J} . g^{-1}\right)$ & 255 & 296 & 364 \\
\hline $\mathrm{Q}_{120}\left({\mathrm{~J} . \mathrm{g}^{-1}}^{-1}\right.$ & 274 & 302 & 392 \\
\hline $\mathrm{Q}_{168}\left({\left.\mathrm{~J} . \mathrm{g}^{-1}\right)}^{\mathrm{n}}\right.$ & 294 & 303 & 406 \\
\hline Maximal heating $\left({ }^{\circ} \mathrm{C}\right)$ & 25.6 & 29.3 & 36.3 \\
\hline $\mathrm{R}_{\mathrm{c}} 1$ day $(\mathrm{MPa})$ & 8.2 & 13.3 & 15.4 \\
\hline $\mathrm{R}_{\mathrm{c}} 2$ days $(\mathrm{MPa})$ & 20.4 & 24.7 & 27.5 \\
\hline $\mathrm{R}_{\mathrm{c}} 28$ days $(\mathrm{MPa})$ & 39.4 & 49.0 & 60.2 \\
\hline
\end{tabular}

180

181 The cement hydration products, for $\mathrm{W} / \mathrm{C}=0.5$, were studied with $\mathrm{XRD}$ and $\mathrm{XF}$ analysis at

182 different stages of maturity from 15 minutes after mixing to 28 days. Here, only results at 28 days

183 are presented. Weight loss at $500{ }^{\circ} \mathrm{C}$ was measured in order to calculate the bound water and,

184 using Rietveld calculations, the weight fractions of each crystalline phase and of total amorphous

185 was obtained.

186

187 The quantities of Portlandite, ettringite and amorphous phase after 28 days for cements C3, C2

188 and $\mathrm{C} 1$ are presented in Table 3.

189

190 
191 Table 3. Quantities of Portlandite, ettringite and amorphous phase in cement C1, C2 and C3 after

19228 days.

\begin{tabular}{|c|c|c|c|}
\hline Quantity phase (\%) & C1 & C2 & C3 \\
\hline Portlandite & 11 & 16 & 13 \\
\hline Ettringite & 14 & 13 & 5 \\
\hline Amorphous phase & 60 & 68 & 28 \\
\hline
\end{tabular}

193

194

195

196

197

198

199

200

201

202

203

\subsubsection{Selected additions}

The effect of three concrete additions was studied. These were: a granulated blast furnace slag, with a Blaine surface area equal to $4,230 \mathrm{~cm}^{2} \cdot \mathrm{g}^{-1}$, produced by Ecocem $\mathrm{SA}$; a fly ash from Carling SA, with a Blaine surface area equal to $3,360 \mathrm{~cm}^{2} \cdot \mathrm{g}^{-1}$ and a mechanically densified silica fume (FS95 DM), from Condensil SA. Because of the high silica fume fineness, it was not possible to measure it thanks to Blaine equipment. According to the technical datasheet, the specific surface area of the silica fume is between 150,000 and $350,000 \mathrm{~cm}^{2} \cdot \mathrm{g}^{-1}$. These three additions were added to concrete in the usual percentages, with a variation of $50 \%$ around this value: $50 \%$ for the slag, $25 \%$ for the fly ash and $8 \%$ for the silica fume.

Table 4 shows the physical characteristics of the three selected additions. We can see that the median diameter of the silica fume was larger than that of the slag or the fly ash. This is due to our method which is not powerful enough to break coagulation od silica fume particles. In addition, the activity coefficients were not measured with the three selected cements but with a reference cement as laid down in the standard EN 197-1 [16]. The ratios $\left(\mathrm{R}_{\mathrm{A} / \mathrm{C}}\right)$ between the compressive strengths after 28 days $\left(\mathrm{R}_{100 \mathrm{C}}\right)$ for the 50-50\% slag-cement [69], the 25-75\% fly ash-cement [67] and the 10-90\% silica fume-cement [34] and the $100 \%$ cement gives the 28-day activity coefficients, see equation (2). The ratio 10-90\% silica fume-cement for measuring the 
211 activity coefficient is used according to the standard, even if it is slightly different to our mean

212 value $(8 \%)$

$$
k=\frac{R_{A / C}-R_{100 C}}{R_{100 C}}
$$

213 These values were used in the Bolomey formula, see equation (1), as well as in the concrete mix

214 design tool presented in part 4.4.

215

216 Table 4. Physical characteristics of the three selected additions [16].

\begin{tabular}{|c|c|c|c|}
\cline { 2 - 4 } \multicolumn{1}{c|}{} & Slag & Fly ash & Silica fume \\
\hline $\mathrm{D}_{50}(\mu \mathrm{m})$ & 10.8 & 17.2 & 58.2 \\
\hline Blaine surface area $\left(\mathrm{cm}^{2} . \mathrm{g}^{-1}\right)$ & 4230 & 3360 & $\mathrm{NC}$ \\
\hline Density $\left(\mathrm{g} . \mathrm{cm}^{-3}\right)$ & 2.96 & 2.31 & 2.27 \\
\hline 28-day activity coefficient & 0.9 & 0.8 & 1.2 \\
\hline
\end{tabular}

218 Finally, the chemical admixture used here was a MasterPolyheed 650 superplasticizer from 219 BASF.

\subsection{Notation}

222 A notation was applied for the concretes based on the three factors:

$$
\text { Cx_\%Addition_W/B_\%Admixture }
$$

$224-$ Cx which indicates the type of cement $-\mathrm{C} 1, \mathrm{C} 2$ or C3,

225 - \%Addition which indicates the percentage of addition and is followed by the suffix $\mathrm{S}$ for

226 slag, FA for fly ash or SF for silica fume,

- W/B which indicates the water-to-binder (cement + addition) ratio,

- \%Admixture which indicates the percentage of chemical admixture. 


\subsection{Experimental design}

231 Screening experimental design was used to study the impact of parameters on hydration heat and 232 mechanical strength. To do this, and limit the number of experiments, only five parameters were 233 varied over three different levels: addition-to-binder ratio, type of cement, type and quantity of 234 additions, water-to-binder ratio and percentage of chemical admixture, see Figure 1. With this 235 type of experimental design, it is possible to observe not only the effect of each parameter, but 236 also the interaction between them. The total quantity of cement and addition was fixed at 360 $237 \mathrm{~kg} \cdot \mathrm{m}^{-3}$. Because of the variation in the quantity of the addition for each addition, the addition-to238 binder ratio varied by $50 \%$ around a nominal value.

240 Figure 1. Diagram representing the parameters studied in our concrete experimental design.

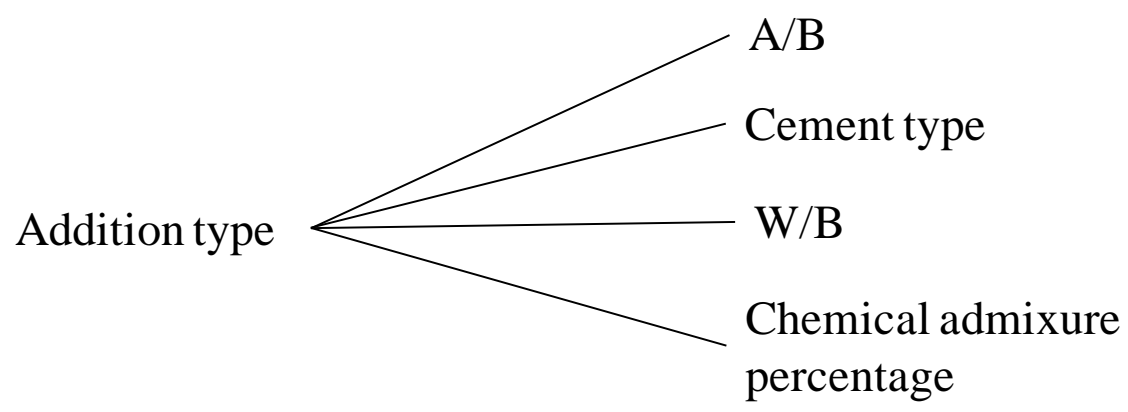

243 Considering the various cements and additions water demand, the chemical admixture percentage 244 varies more or less $15 \%$ around a nominal value in order to obtain fluid, or at least not too dry, 245 concretes at fresh state.

246 Erreur ! Source du renvoi introuvable.Table 5 shows the parameters and their levels (cement 247 type, type and quantity of addition, W/B, chemical admixture). 
249 Table 5. Levels and parameters selected for this experimental design.

\begin{tabular}{|c|c|c|c|c|c|c|c|c|c|}
\hline Parameter & \multicolumn{9}{|c|}{ Level } \\
\hline Addition type & \multicolumn{3}{|c|}{ Slag } & \multicolumn{3}{|c|}{ Fly ash } & \multicolumn{3}{|c|}{ Silica fume } \\
\hline $\begin{array}{l}\text { Addition quantity } \\
\text { for } 100 \mathrm{~kg} \text { of cement } \\
\text { (kg/100kg of } \\
\text { cement) }\end{array}$ & 25.0 & 50.0 & 75.0 & 12.5 & 25.0 & 37.5 & 4.0 & 8.0 & 12.0 \\
\hline Cement type & \multicolumn{3}{|c|}{$\mathrm{C} 1$} & \multicolumn{3}{|c|}{$\mathrm{C} 2$} & \multicolumn{3}{|c|}{ C3 } \\
\hline $\mathrm{W} / \mathrm{B}$ & \multicolumn{3}{|c|}{0.375} & \multicolumn{3}{|c|}{0.400} & \multicolumn{3}{|c|}{0.425} \\
\hline $\begin{array}{c}\text { Chemical admixture } \\
(\%)\end{array}$ & 0.38 & 0.45 & 0.52 & 0.51 & 0.60 & 0.69 & 0.85 & 1.00 & 1.15 \\
\hline
\end{tabular}

250

251 The name and formulation of concretes studied in this article are presented in appendix A.

$252 \quad 3.4$ Analytical techniques

253 The concretes were characterized:

254 - in the fresh state, by measuring slump according to the standard EN 12350-2 [68],

255 - thermally, by measuring the hydration heat with quasi-adiabatic calorimetry QAC

256 according to the standard EN 12390-14 [69]. Figure 2 shows an example of the result of

257 such a test.

258 - mechanically, by measuring compressive strengths on 16x32cm cylindrical specimens

259 according to the standard EN 12390-3 [70].

260

261 Figure 2. Example of the result of quasi-adiabatic calorimetric test (QAC). Case of the concrete

262 C1_25S_0.375_0.45. $\mathrm{T}_{\max \_\mathrm{QAC}}$ corresponds to the maximal temperature measured during the test

263 and $\mathrm{T}_{\text {max_adia }}$ to the final temperature obtained after correction due to the losses of the calorimeter

264 (and that are estimated with the method proposed by EN 12390-14). 


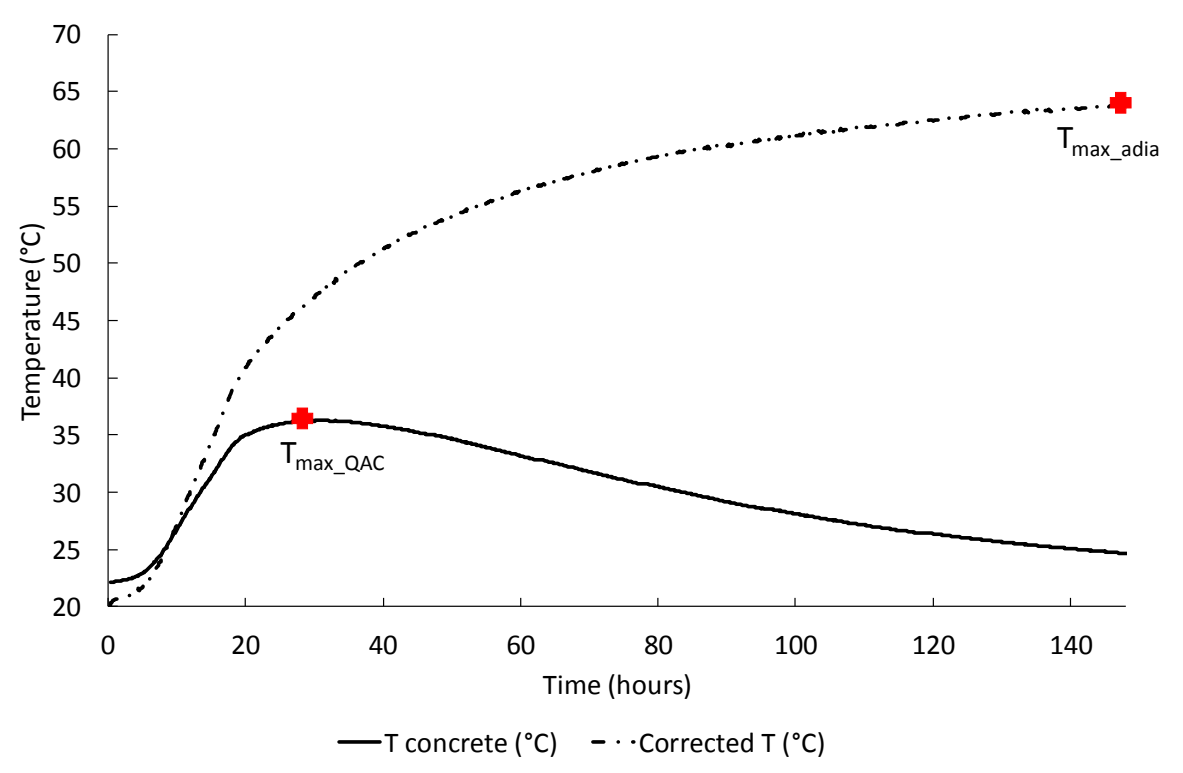

\section{RESULTS AND DISCUSSION}

268 In this section, we shall present and discuss the results from the experimental design, especially 269 with regard to the fresh state and changes in the hydration heat and compressive strength. The 270 fresh state characteristics were measured but were not included in our mix design tool. The 271 figures below present the median effects in black and the interaction between factors in blue for

272 slag (S), red for fly ash (FA) and green for silica fume (SF). The interactions were analyzed by a 273 comparison with the general trend. If the change was similar but with just a vertical displacement, 274 no interaction was deemed to take place between the type of addition and the other factors. On 275 the other hand, if the trend was reversed, there a considerable interaction was deemed to take 276 place between the type of addition and the other factors.

\subsection{Influence of the factors on concrete in the fresh state}

279 Figure 3 presents the effects of the different factors and their mutual interactions on concrete 280 slump in the fresh state. Generally, the use of slag and fly ash in concrete leads to more slump 
281 than silica fume. This is due to the clustering of silica fume which means that water is confined

282 within it. Because of this, less water is available to increase concrete fluidity. The difference in

283 slump between slag and fly ash concretes is explained by the fact that fly ash has a spherical

284 specific surface [32] whereas that of slag is granular [33]. The higher the quantity of addition, the 285 greater the slump, except when silica fume is added.

286

287 Figure 3. Median effects of factors and their interactions on concrete slump.

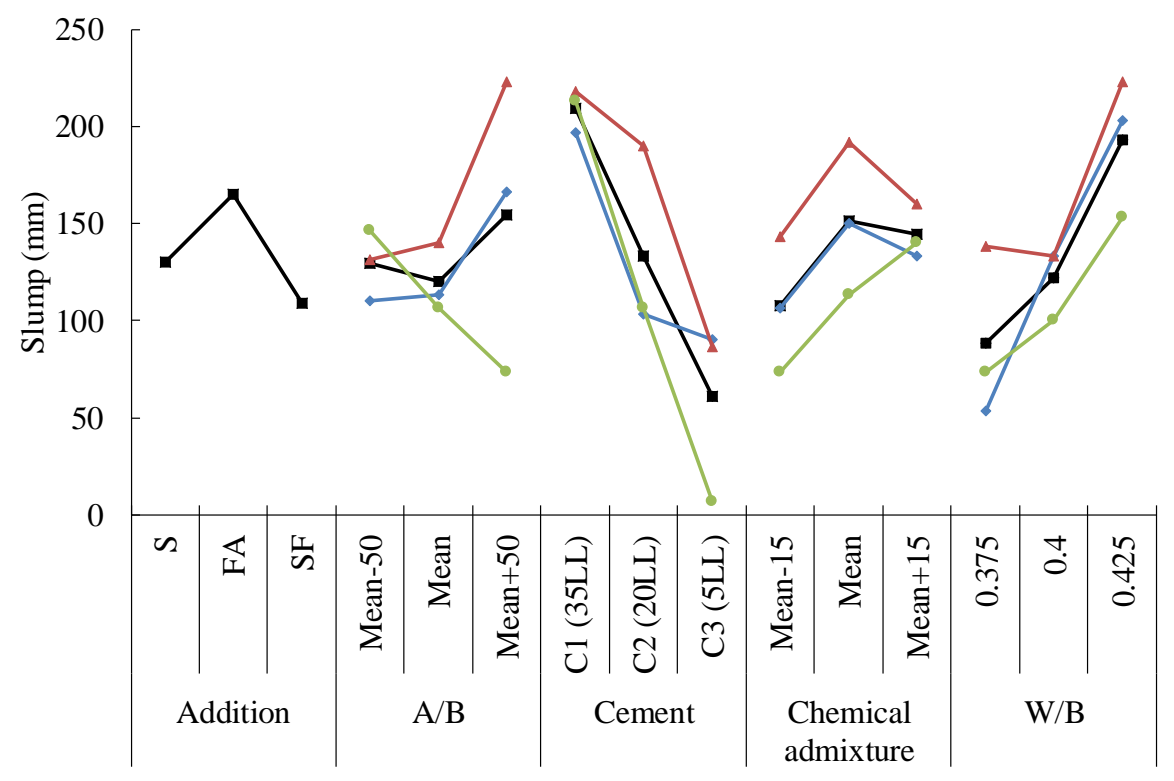

290 The types of cement used in the concrete also had an impact on the fresh state, regardless of the 291 type of addition, although this could increase water demand. This is due to the wide variation in

292 the characteristics of cements, and in particular their water demand. The closer the composition 293 of the cement was to CEM I, the higher the water demand. 
294 Due to its fluidizing effect, beyond a certain quantity, the chemical admixture increased the slump

295 of the concrete. However, the full effect of chemical mixing was not achieved because the mixing

296 time was not optimized (we were close to field conditions).

297 The type of addition can interact with the chemical admixture. Bessa-Badreddine report that the

298 smaller the amount of the addition, the greater the demand for the chemical admixture [19].

299 Finally, as expected, an increase in the water-to-binder ratio increased the slump.

300

$301 \quad 4.2$ Influence of the factors on hydration heat

302 It is also important to study temperature rise in massive concrete structures in order to prevent the

303 risk of both DEF and cracking. To do this, the calorimetric measurement of temperature during

304 concrete hydration was analyzed, giving the hydration heat after $41 \mathrm{~h}$, see 
305 Figure 4 and after 144h, see Figure 5. In general, we can see that concrete additions reduced the

306 hydration heat, to an extent that increased with their quantity. However, this effect was less

307 visible for silica fume, because of the lower quantity used (4 to $12 \%$ compared to 12.5 to 37.5

308 and 25 to $75 \%$ for fly ash and slag) and its higher reactivity. Slag and fly ash produce less heat

309 than silica fume, after both $41 \mathrm{~h}$ and $144 \mathrm{~h}$. Indeed, like pozzolanic materials, they react slowly and

310 need activation, while silica fume is very reactive due to its fineness and its role as a nucleation

311 site [55]. The difference in heat flow between slag and fly ash decreased with time, and led to

312 values that were equivalent for the two, or even higher for slag than fly ash, after 144h. These

313 values agreed with the measured activity coefficients (see Erreur ! Source du renvoi

314 introuvable.).

315 
316 Figure 4. Median effects of factors and their interactions on the QAC hydration heat of concrete

317 after 41 hours.

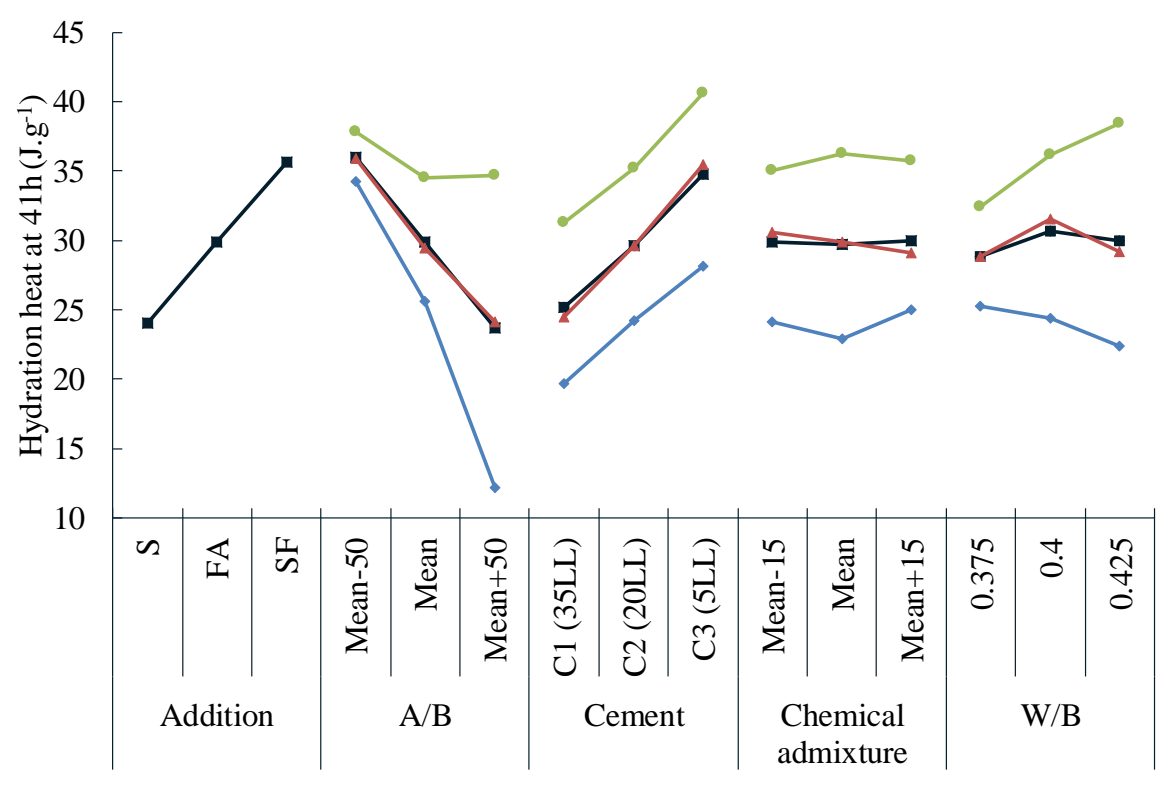

320 Figure 5. Median effects of factors and their interactions on the QAC hydration heat of concrete 321 after 144 hours.

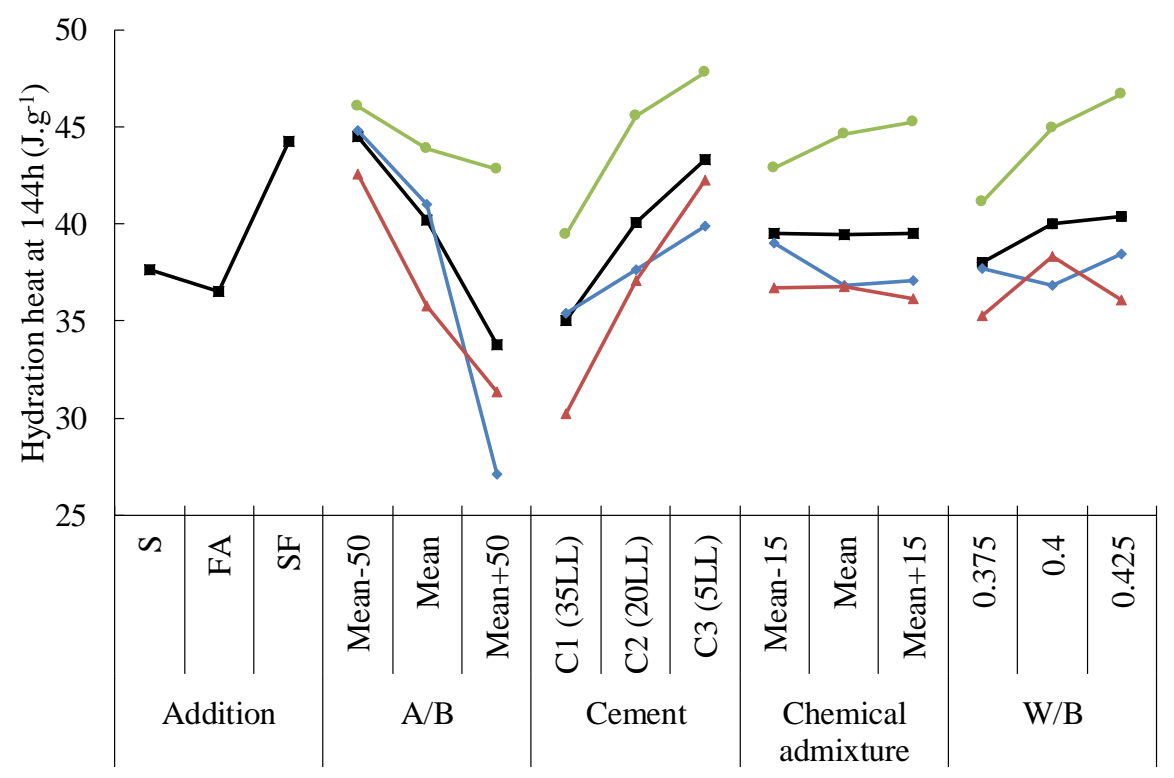


324 As in the case of slump, we could observe the effect of cement type on the hydration heat after

$32541 \mathrm{~h}$ and $144 \mathrm{~h}$, whatever the type of addition. The more diluted the clinker part of the cement

326 (presence of limestone), the lower the hydration heat. However, in contrast to slump, the

327 percentage of chemical admixture did not affect hydration heat production, whatever the maturity

328 and the addition type. Finally, the water-to-binder ratio did not influence early age hydration heat

329 production and affected that after $144 \mathrm{~h}$ very little, but our experimental design did not vary the

330 W/B ratio by a large amount. It is also possible to see a small difference between concretes with

331 silica fume when the W/B ratio increased: more water was free for hydration reactions so the

332 hydration heat produced increased with $\mathrm{W} / \mathrm{B}$ ratio.

$333 \quad 4.3$ Influence of the factors on compressive strength

334 Figure 6 and Figure 7 respectively show the median effect and interactions of the factors on the 335 compressive strength of the concrete after 2 and 28 days. It is possible to draw a parallel between

336 the median effects of factors and their interactions with regard to hydration heat and compressive

337 strength. Silica fume gives higher compressive strength than fly ash and slag after 2 and 28 days,

338 which agrees with their activity coefficients. Moreover, as Pertué has reported, such differences

339 in early age strength can be explained by the difference between the kinetic of hydration

340 reactions, as evidenced by heat measurements [71]. However, the compressive strengths of

341 concrete with slag are lower than with fly ash because of the higher percentage of slag (less

342 cement). Even if at early age, it is difficult to see an interaction between the cement and the type

343 of addition, the strengths with greater maturity show such an interaction, predominantly for slag 344 and silica fume. 
346 Figure 6. Median effects of factors and their interactions on the 2-day compressive strength of 347 concrete.

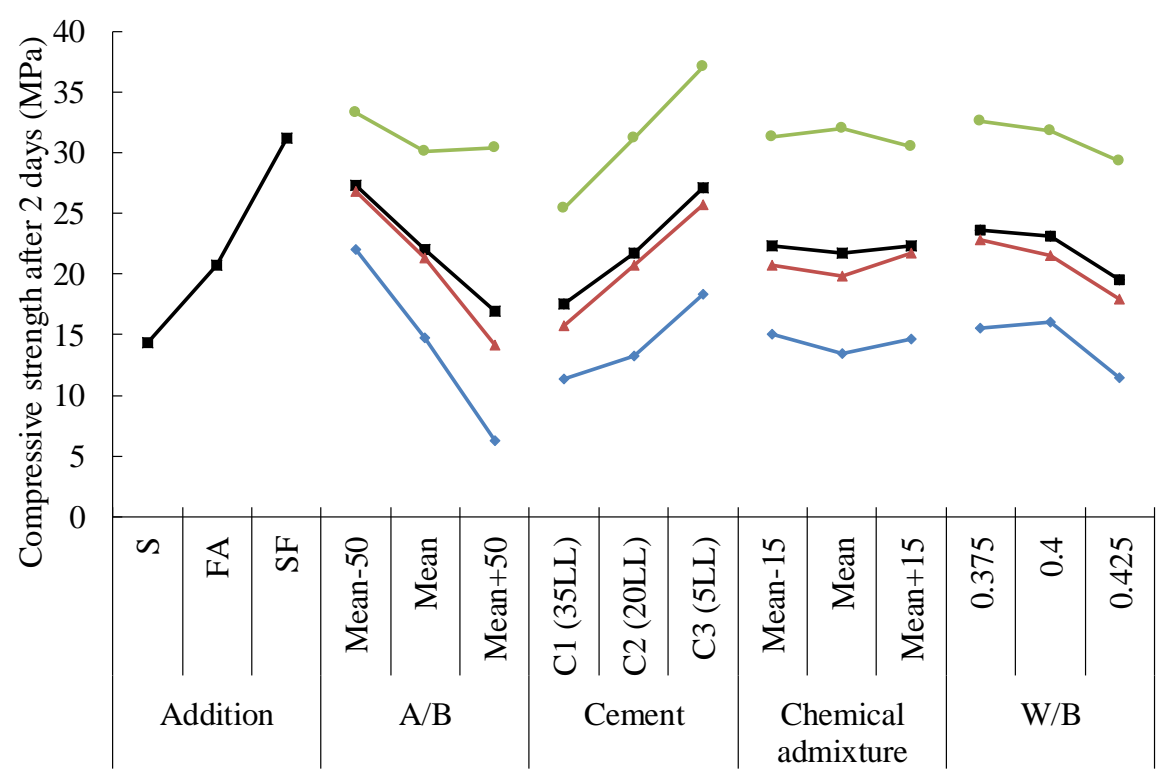

350 Figure 7. Median effects of factors and their interactions on the 28-day compressive strength of 351 concrete.

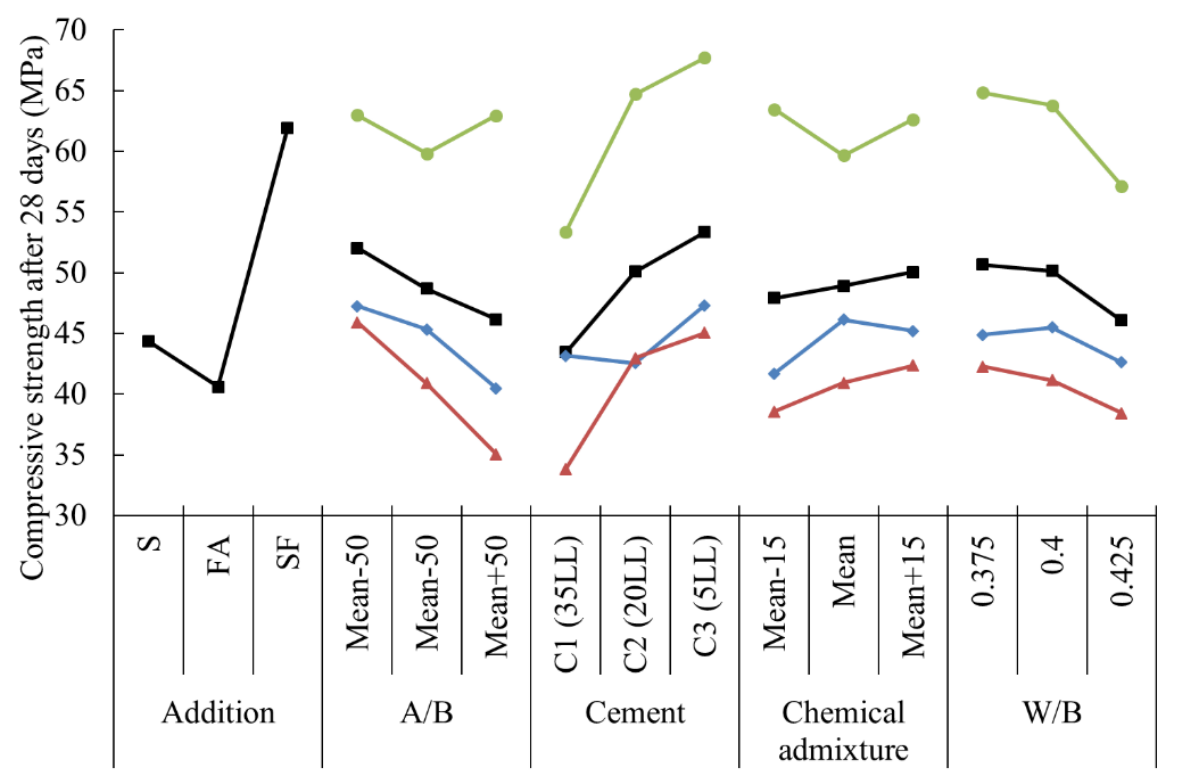


354 Compressive strength decreased with the quantity of additions. Interaction with the type of

355 addition was low, except for silica fume due to its high water demand and reactivity. The

356 chemical admixture had no effect on strength, irrespective of the type and quantity of additions.

357 Lastly, a small effect, resulting from a small variation in the water-to-binder ratio, on compressive

358 strength is visible, with no interaction with the type of addition.

$359 \quad$ 4.4 Concrete mix design tool

360 The above analysis of the median effects and interactions provides the opportunity to create a

361 model for several answers according to each factor. The percentage of chemical admixture is not

362 taken into account in this model because of its minor impacts on the characteristics of concrete.

363 Combining these model equations provides us with a concrete mix design tool that enables

364 specified requirements to be met. Generally, the answer X is calculated using equation (3) and

365 corresponds to the sum of the median value of the answer $\mathrm{X}$ for the addition $\mathrm{A} \overline{X_{A}}$, the variation

366 generated by the percentage of addition $\Delta X_{\% A}$, the variation resulting from the W/B ratio $\Delta X_{\frac{W}{B}}$

367 and the variation arising from the cement type $\mathrm{C} \Delta X_{C}$.

$$
X=\overline{X_{A}}+\Delta X_{\%_{A} A}+\Delta X_{\bar{B}}+\Delta X_{C}
$$

368 Equations (4), (5) and (6) correspond respectively to the variations resulting from the cement

369 type, the W/B ratio and the percentage of additions. These variations correspond to the difference

370 between the median value of the answer $\mathrm{X}$ for addition $\mathrm{A} \overline{X_{A}}$ and cement $\mathrm{C} \overline{X_{C}}$, see equation (4),

371 and the function $f_{x}(\% A)$ and $f_{x}\left(\frac{W}{B}\right)$ - obtained from the effect and interaction analyze for the

372 answer $\mathrm{X}$ - and the median value of the answer $\mathrm{X}$ for addition $\mathrm{A}$, see equations (5) and (6).

$$
\Delta X_{C}=\overline{X_{C}}-\overline{X_{A}}
$$




$$
\begin{gathered}
\Delta X_{\frac{W}{B}}=f_{x}\left(\frac{W}{B}\right)-\overline{X_{A}} \\
\Delta X_{\% A}=f_{x}(\% A)-\overline{X_{A}}
\end{gathered}
$$

373 Table 6 presents the equations and the data used to calculate the maximum temperature in the

374 calorimeter measured during concrete hydration $\left(\mathrm{T}_{\text {max }_{-} \mathrm{QAC}}\right)$, the maximum adiabatic temperature

375 ( $\left.\mathrm{T}_{\text {adia_max }}\right)$ and the compressive strength after 2 and 28 days $\left(\mathrm{R}_{\mathrm{c}} 2\right.$ and $\left.\mathrm{R}_{\mathrm{c}} 28\right)$. With finite element

376 modelling of the quasi-adiabatic test [72], it has been established that $\mathrm{T}_{\max \_\mathrm{QAC}}$ corresponds to the

377 temperature measured in a concrete structure with a notional size of $40 \mathrm{~cm}$ while $\mathrm{T}_{\text {adia_max }}$ 378 corresponds to the temperature measured in massive concrete structures with a notional size of 379 several meters.

380

381 Table 6. Equations and data used for the concrete mix design tool.

\begin{tabular}{|c|c|c|c|c|c|c|c|}
\cline { 2 - 8 } \multicolumn{2}{c|}{} & $\bar{X}_{A}$ & Addition (\%) & Ratio $\frac{W}{B_{\text {tot }}}$ & $\bar{X}_{C 1}$ & $\bar{X}_{C 2}$ & $\bar{X}_{C 3}$ \\
\hline \multirow{2}{*}{\begin{tabular}{c}
$\mathrm{T}_{\text {max_QAC }}\left({ }^{\circ} \mathrm{C}\right)$ \\
\cline { 2 - 8 }
\end{tabular}} & $\mathrm{S}$ & 34.3 & $-0.19 . \% A+9.39$ & $0.67 \cdot \frac{W}{B_{\text {tot }}}+3.32$ & 31.8 & 34.4 & 36.8 \\
\cline { 2 - 8 } & $\mathrm{FA}$ & 37.0 & $-0.26 . \% A+6.39$ & $-32.00 \cdot \frac{W}{B_{\text {tot }}}+9.02$ & 34.8 & 37.5 & 41.5 \\
\hline \multirow{2}{*}{$\begin{array}{c}\mathrm{T}_{\text {adia_max }} \\
\left({ }^{\circ} \mathrm{C}\right)\end{array}$} & $\mathrm{SF}$ & 41.6 & $-0.16 . \% A+1.31$ & $51.33 \cdot \frac{W}{B_{\text {tot }}}-20.54$ & 38.6 & 41.4 & 44.7 \\
\cline { 2 - 8 } & $\mathrm{FA}$ & 65.2 & $-0.46 . \% A+11.50$ & $-1.95 \cdot \frac{W}{B_{\text {tot }}}+0.79$ & 51.5 & 58.5 & 63.9 \\
\cline { 2 - 8 } & $\mathrm{SF}$ & 66.0 & $-0.42 . \% A+3.47$ & $92.23 . \frac{W}{B_{\text {tot }}}-36.89$ & 61.0 & 67.3 & 69.7 \\
\hline
\end{tabular}




\begin{tabular}{|c|c|c|c|c|c|c|c|}
\hline \multirow{2}{*}{$\begin{array}{c}\mathrm{R}_{\mathrm{c}} 2 \\
\text { days } \\
(\mathrm{MPa})\end{array}$} & $\mathrm{S}$ & 14.3 & $-0.31 . \% A+15.417$ & $-79.50 \cdot \frac{W}{B_{\text {tot }}}+31.83$ & 11.4 & 13.3 & 18.4 \\
\cline { 2 - 8 } & $\mathrm{FA}$ & 20.8 & $-0.44 . \% A+10.86$ & $98.00 \cdot \frac{W}{B_{\text {tot }}}+39.20$ & 15.7 & 20.8 & 25.8 \\
\hline \multirow{2}{*}{$\begin{array}{c}\mathrm{R}_{\mathrm{c}} 28 \\
\text { days } \\
(\mathrm{MPa})\end{array}$} & $\mathrm{SF}$ & 41.3 & $-0.35 . \% A+2.92$ & $-66.00 \cdot \frac{W}{B_{\text {tot }}}+26.06$ & 25.4 & 31.2 & 37.1 \\
\cline { 2 - 9 } & $\mathrm{FF}$ & 40.6 & $-0.43 . \% A+10.74$ & $-76.67 \cdot \frac{W}{B_{\text {tot }}}+30.45$ & 33.9 & 43.0 & 45.0 \\
\hline
\end{tabular}

\subsection{Application}

384 In this section, the application of this mix design tool to meet specified requirements (Table 7)

385 and to minimize the maximum temperature in a structure with a notional size of $40 \mathrm{~cm}$ is

386 presented.

387

388 Table 7. Specific requirements.

\begin{tabular}{|c|c|}
\hline Addition percentage according to standard EN $206 / \mathrm{CN}$ & $0<\mathrm{S}<0.4$ \\
NAF 1 & $0<\mathrm{FA}<0.3$ \\
& $0<\mathrm{SF}<0.1$ \\
\hline $\mathrm{W} / \mathrm{B}$ & $0.3<\mathrm{W} / \mathrm{B}<0.6$ \\
\hline $\mathrm{B}_{\text {eq }}(\mathrm{kg})$ & $280<\mathrm{B}_{\text {eq }}<400$ \\
\hline Volume of paste $(\mathrm{L})^{\mathrm{T}_{\text {max_QAC }}\left({ }^{\circ} \mathrm{C}\right)}$ & $\mathrm{V}_{\text {paste }} \geq 250$ \\
\hline $\mathrm{R}_{\mathrm{c}} 28$ days for C30 $(\mathrm{MPa})$ & minimal \\
\hline
\end{tabular}

389

390 Equation (7) is used to calculate the volume of pasteV $V_{\text {paste }}$ considering the water to binder ratio

$391 \frac{W}{B}$, the total binder $B_{t o t}$, the addition mass $m_{a d d}$ and density $\rho_{a d d}$ and the cement density $\rho_{c}$. 


$$
V_{\text {paste }}=\frac{W}{B} \cdot B_{t o t}+\frac{m_{a d d}}{\rho_{a d d}}+\frac{B_{t o t}-m_{a d d}}{\rho_{c}}
$$

392 The parameters in this mix design tool are the type and quantity of cement, of addition and the

393 quantity of water. The working limits were defined on the basis of the standard

394 EN 206 NAF 1 [7] for an XC4 exposure grade (corrosion by carbonation and variable presence of

395 water) and presented in Erreur ! Source du renvoi introuvable.

396 . Note that, like the experimental design, the mix design tool has been created for concrete with a

397 fixed granular skeleton. The equivalent binder $B_{e q}$ corresponds to the sum of the quantity of 398 cement $\mathrm{C}$ and the activity coefficient $\mathrm{k}$ of the addition multiplied by the addition quantity $\mathrm{A}$ as 399 defined in equation (8).

$$
B_{e q}=C+k \cdot A
$$

400 Table 8 presents the nine optimized mix designs (3 different cements with 3 different additions).

401 Firstly, we can see that the 28-day compressive strength of the concretes was above $38 \mathrm{MPa}$ when 402 silica fume was used (mix designs 7 to 9). Three mix designs gave compressive strengths 403 between 38 and 40MPa (mix designs 2, 4 and 5). As we have already seen, slag leads to higher 404 QAC hydration heat and temperature than fly ash (more than $10^{\circ} \mathrm{C}$ difference between concretes 405 with slag and those with fly ash). For the two last concretes (mix designs 4 and 5), it was the high 406 amount of limestone in $\mathrm{C} 1$ that limited the temperature rise $\left(28.4^{\circ} \mathrm{C}\right)$ while both reach $38 \mathrm{MPa}$ 407 after 28 days. 
Table 8. Tested concrete mix designs.

\begin{tabular}{|c|c|c|c|c|c|c|c|c|c|c|}
\hline Mix design number & 1 & 2 & 3 & 4 & 5 & 6 & 7 & 8 & 9 \\
\hline Addition type & \multicolumn{3}{|c|}{$\mathrm{S}$} & \multicolumn{3}{|c|}{$\mathrm{F} A$} & \multicolumn{3}{|c|}{$\mathrm{SF}$} \\
\hline Cement type & $\mathrm{C} 1$ & $\mathrm{C} 2$ & $\mathrm{C} 3$ & $\mathrm{C} 1$ & $\mathrm{C} 2$ & $\mathrm{C} 3$ & $\mathrm{C} 1$ & $\mathrm{C} 2$ & $\mathrm{C} 3$ \\
\hline Equivalent binder $(\mathrm{kg})$ & 389 & 387 & 390 & 364 & 390 & 280 & 395 & 400 & 395 \\
\hline $\mathrm{A} / \mathrm{B}$ & 0.40 & 0.40 & 0.40 & 0.30 & 0.30 & 0.30 & 0.10 & 0.10 & 0.10 \\
\hline $\mathrm{W} / \mathrm{B}_{\mathrm{eq}}$ & 0.30 & 0.30 & 0.30 & 0.47 & 0.47 & 0.60 & 0.30 & 0.30 & 0.32 \\
\hline $\mathrm{T}_{\text {max_QAC }}\left({ }^{\circ} \mathrm{C}\right)$ & 37.1 & 40.1 & 43.9 & 28.2 & 31.3 & 31.3 & 31.9 & 36.6 & 40.7 \\
\hline $\mathrm{T}_{\text {adia_max }}\left({ }^{\circ} \mathrm{C}\right)$ & 65.0 & 70.7 & 73.2 & 49.1 & 56.1 & 61.3 & 51.9 & 58.2 & 62.3 \\
\hline $\mathrm{Rc}_{2}$ days $(\mathrm{MPa})$ & 23.5 & 25.3 & 30.5 & 10.3 & 15.3 & 8.3 & 30.5 & 36.3 & 42.1 \\
\hline $\mathrm{R}_{\mathrm{c}} 28$ days $(\mathrm{MPa})$ & 49.3 & 40.4 & 59.5 & 38.1 & 38.1 & 50.5 & 60.7 & 58.7 & 80.0 \\
\hline
\end{tabular}

409

410 A further condition was then added to the specified requirements, namely a minimum 2-day

411 compressive strength of $20 \mathrm{MPa}$. The mix designs are presented in Table 9. Concretes 1 to 3 and

4127 to 9 already met the two compressive strength conditions and have therefore not been modified.

413

414 Table 9. Tested concrete mix design meeting the specified requirements with a minimum

415 temperature in the QAC test and a 2-day compressive strength of at least $20 \mathrm{MPa}$.

\begin{tabular}{|c|c|c|c|c|c|c|c|c|c|c|}
\hline Mix design number & 1 & 2 & 3 & 4 & 5 & 6 & 7 & 8 & 9 \\
\hline Addition type & \multicolumn{3}{|c|}{$\mathrm{S}$} & \multicolumn{3}{|c|}{ FA } & \multicolumn{3}{c|}{ SF } \\
\hline $\begin{array}{c}\text { Cement type } \\
\text { Equivalent binder } \\
(\mathrm{kg})\end{array}$ & $\mathrm{C} 1$ & $\mathrm{C} 2$ & $\mathrm{C} 3$ & $\mathrm{C} 1$ & $\mathrm{C} 2$ & $\mathrm{C} 3$ & $\mathrm{C} 1$ & $\mathrm{C} 2$ & $\mathrm{C} 3$ \\
\hline $\mathrm{A} / \mathrm{B}$ & 0.40 & 0.40 & 0.40 & 0.30 & 0.30 & 0.30 & 0.10 & 0.10 & 0.10 \\
\hline $\mathrm{W} / \mathrm{B}_{\text {eq }}$ & 0.30 & 0.30 & 0.30 & 0.36 & 0.42 & 0.47 & 0.30 & 0.30 & 0.32 \\
\hline $\mathrm{T}_{\text {max_QAC }}\left({ }^{\circ} \mathrm{C}\right)$ & 37.1 & 40.1 & 43.9 & 31.4 & 32.8 & 35.1 & 31.9 & 36.6 & 40.7 \\
\hline $\mathrm{T}_{\text {adia_max }}\left({ }^{\circ} \mathrm{C}\right)$ & 64.8 & 70.6 & 73.1 & 49.3 & 56.2 & 61.5 & 51.9 & 58.2 & 62.3 \\
\hline $\mathrm{Rc}_{2} 2$ days $(\mathrm{MPa})$ & 23.5 & 25.3 & 30.5 & 20.0 & 20.0 & 20.0 & 30.5 & 36.3 & 42.1 \\
\hline $\mathrm{R}_{\mathrm{c}} 28$ days $(\mathrm{MPa})$ & 49.3 & 40.4 & 59.5 & 45.7 & 41.8 & 59.6 & 60.7 & 58.7 & 80.0 \\
\hline
\end{tabular}

416 
417 This time, we can see that all the concretes have a 2-day compressive strength of at least $20 \mathrm{MPa}$

418 and that the maximum temperature in the quasi-adiabatic test stays below $44{ }^{\circ} \mathrm{C}$. With regard to

419 this temperature, fly ash concretes are not the only ones to exhibit a low temperature rise. Indeed,

420 mix designs 7 and 8 - made with silica fume - generate the same heat as fly ash concretes (mix

421 designs 4 to 6 ), and even less heat than concretes with slag (mix designs 1 to 3 ). Contrary to what

422 was expected, slag concretes are more exothermic and have lower 2-day compressive strengths

423 than silica fume concretes.

424 Otherwise, when considering larger concrete structures, the temperature is closer to the adiabatic

425 temperature. For at least $7 \mathrm{mix}$ designs, the adiabatic temperature is close to $65{ }^{\circ} \mathrm{C}$, and 426 sometimes $75{ }^{\circ} \mathrm{C}$ for slag concrete. Such high adiabatic temperatures can increase the risk of 427 cracking. Lower temperatures than with slag concretes can be obtained with mix designs 428 containing fly ash followed by designs containing silica fume. This could be explained by two 429 things: firstly, fly ash is slightly less reactive than slag, and secondly, silica fume concrete mix 430 designs may be optimized with reference to the minimum temperature in the quasi-adiabatic test 431 but if this is the case, the water-to-binder ratio is very low. This means the cement and silica fume 432 have a low level of hydration and therefore a lower adiabatic temperature compared to slag 433 concrete. It is possible to have a water-to-binder ratio equal to 0.3 for silica fume concrete but 434 due to higher water demand, a large amount of superplasticizer is needed. If a higher water-to435 binder ratio is used, the cement and the silica fume will be more hydrated leading to higher 436 temperatures in massive concrete structures.

437 When heat release is considered in this mix design tool, the importance of the size of the structure 438 is apparent: mix design can only be optimized on the basis of the size of the structure matching 439 with the environment temperature or construction procedure. 


\section{5. CONCLUSION}

442 This study has allowed us to show the effect of the type and percentage of additions, cement 443 composition, water-to-binder ratio and the quantity of chemical admixture on concrete in the

444 fresh state and later on hydration heat and compressive strength. Concrete slump is influenced by 445 the cement-addition combination and by the quantity of water and chemical admixture, which

446 deflocculates particles and provides free water for fluidity and concrete hydration. As a general 447 rule, concrete slump increases with the amount of addition, except when silica fume is used as an 448 addition.

449 After setting, the water-to-binder ratio and the amount of chemical admixture have little effect on 450 the hydration heat compared to the type of cement and addition. The greater the amount of 451 addition, the lower the heat flow. The hydration kinetic is faster for concrete with silica fume than 452 for concrete with slag or fly ash. As far as compressive strength is concerned, both at early age or 453 later, it is the cement-addition combination that is important, in addition to the activity coefficient 454 of the addition.

455 Finally, this study has enabled us to develop a concrete mix design tool that enables specified 456 requirements to be met. For example, this tool allows the optimization of concrete mix design 457 when certain temperatures during hydration or certain mechanical strengths are needed for a 458 given environmental exposition and shows how important the size of the considered structure is 459 in order to optimize the mix design. Of course, our tool does not take account of other factors that 460 should also be considered during concrete mix design, such as durability, environmental impact 461 and cost. 


\section{REFERENCES}

463 [1] IFSTTAR, Recommendations for preventing disorders due to Delayed Ettringite Formation

[2] M. Al Shamaa, S. Lavaud, L. Divet, G. Nahas, J.M. Torrenti, Influence of relative humidity on delayed ettringite formation, Cem. Concr. Compos. 58 (2015) 14-22. doi:http://dx.doi.org/10.1016/j.cemconcomp.2014.12.013.

[3] H.Y. Ghorab, E.A. Kishar, Studies on the stability of the calcium sulfoaluminate hydrates. Part 1: Effect of temperature on the stability of ettringite in pure water, Cem. Concr. Res. 15 (1985) 93-99.

[4] G. De Schutter, L. Taerwe, Degree of hydration-based description of mechanical properties of early age concrete, Mater. Struct. 29 (1996) 335-344.

[5] F. de Larrard, Concrete Mixture Proportioning: A Scientific Approach - CRC Press Book, 1999.

[6] G. Arliguie, H. Hornain, GranDuBé: grandeurs associées à la durabilité des bétons, Presses de l'École nationale des ponts et chaussées, 2007. http://books.google.fr/books?id=0hUQMCJG9q0C (in French).

[7] AFNOR, NF EN 206-1/CN Béton. Spécification, performance, production et conformité Complément national à la norme NF EN 206-1, 2012 (in French).

[8] ACI R 211.1, Standard practice for selecting proportions for normal, heavyweight, and mass concrete. ACI Manual of Concrete Practice, Part 1, Concrete Institute, Farmington hills, MI, 2005.

[9] EN 12620 Aggregates for concrete, 2008.

[10] J. Byfors, Plain concrete at early age, Swedish Cement and Concrete Research Institute, 1980.

[11] H. Minard, Etude intégrée des processus d'hydratation, de coagulation, de rigidification et de prise pour un système $\mathrm{C} 3 \mathrm{~S}-\mathrm{C} 3 \mathrm{~A}$-sulfates-alcalins, $\mathrm{PhD}$ Thesis, Université de Bourgogne, 2003 (in French).

[12] W. Lerch, R.H. Bogue, Heat of hydration of portland cement pastes, J. Res. Natl. Bur. Stand. 12 (1934) 645-664.

[13] D.P. Bentz, E.J. Garboczi, C.J. Haecker, O.M. Jensen, Effects of cement particle size distribution on performance properties of Portland cement-based materials, Cem. Concr. Res. 29 (1999) 1663-1671. doi:http://dx.doi.org/10.1016/S0008-8846(99)00163-5.

[14] D.P. Bentz, Blending different fineness cements to engineer the properties of cement-based materials, Mag. Concr. Res. 62 (2010) 327-338.

[15] M.M. Costoya Fernandez, Effect of particle size on the hydration kinetics and microstructural development of tricalcium silicate, Thesis, Thèse de l'Ecole Polytechnique Fédérale de Lausanne, 2008.

[16] EN 197-1 Cement - Part 1: Composition, specifications and conformity criteria for common cements, 2012.

[17] E. Gartner, Industrially interesting approaches to "low-CO2" cements, Cem. Concr. Res. 34 (2004) 1489-1498.

[18] H.F.. Taylor, Cement Chemistry, 2nd Edition, Thomas Telford, London, 1997.

[19] A. Bessa-Badreddine, Etude de la contribution des additions minérales aux propriétés physiques, mécaniques et de durabilité des mortiers, PhD Thesis, Université de CergyPontoise, 2004 (in French). 
507

508

509

510

511

512

513

514

515

516

517

518

519

520

521

522

523

524

525

526

527

528

529

530

531

532

533

534

535

536

537

538

539

540

541

542

543

544

545

546

547

548

549

550

551

[20] I. Joudi-Bahri, A. Lecomte, M.B. Ouezdou, T. Achour, Use of limestone sands and fillers in concrete without superplasticizer, Cem. Concr. Compos. 34 (2012) 771-780. doi:https://doi.org/10.1016/j.cemconcomp.2012.02.010.

[21] P. Diederich, Contribution à l'étude de l'influence des propriétés des fillers calcaires sur le comportement autoplaçant du béton, PhD Thesis, Université Toulouse III - Paul Sabatier, 2010 (in French).

[22] M.R. Jones, L. Zheng, M.D. Newlands, Estimation of the filler content required to minimise voids ratio in concrete, Mag. Concr. Res. 55 (2003) 193-202.

[23] E. Berodier, K. Scrivener, Understanding the Filler Effect on the Nucleation and Growth of C-S-H, J. Am. Ceram. Soc. 97 (2014) 3764-3773. doi:10.1111/jace.13177.

[24] H. Justnes, I. Meland, J.O. Bjoergum, J. Krane, The mechanism of silica fume action in concrete studied by solid state 29Si NMR, in: NMR-Semin., 1992.

[25] Y. Villagran-Zaccardi, E. Gruyaert, N. Alderete, N. De Belie, Influence of particle size ditribution of slag, limestone and fly ash on early hydration of cement assessed by isothermal calorimetry, in: Int. RILEM Conf. Mater. Syst. Struct. Civ. Eng. Concr. Suppl. Cem. Mater., 2016.

[26] B. Lothenbach, K. Scrivener, R.D. Hooton, Supplementary cementitious materials, Cem. Concr. Res. 41 (2011) 1244-1256. doi:http://dx.doi.org/10.1016/j.cemconres.2010.12.001.

[27] A. Schöler, B. Lothenbach, F. Winnefeld, M.B. Haha, M. Zajac, H.-M. Ludwig, Early hydration of SCM-blended Portland cements: A pore solution and isothermal calorimetry study, Cem. Concr. $\quad$ Res. 93 (2017) 71-82. doi:https://doi.org/10.1016/j.cemconres.2016.11.013.

[28] E. Berodier, Impact of the supplementary cementitious materials on the kinetics and microstructural development of cement hydration, Thesis, Thèse de l'Ecole Polytechnique Fédérale de Lausanne, 2015.

[29] G. Van Rompaey, Etude de la réactivité des ciments riches en laitier, à basse température et à court temps, sans ajout chloruré, PhD Thesis, Université libre de Bruxelles, 2006 (in French).

[30] F. Massazza, M. Diamon, Chemistry of hydration of cements and cementious systems, in: 9th Int. Congr. Chem. Cem., 1992: pp. 383-429.

[31] M. Cyr, P. Lawrence, E. Ringot, Efficiency of mineral admixtures in mortars, Quantification of physical and chemical effects of fines admixtures in relation with compressive strength, Cem. Concr. Res. 36 (2006) 264-277.

[32] R.V. Ramachandran V. S. Mortel N., Concrete admixtures Handbook, Prop. Sci. Technol. (1995).

[33] A. Boudchicha, Utilisation des additions minérales et des adjuvants fluidifiants pour l'amélioration des propriétés rhéologiques et mécaniques des bétons, $\mathrm{PhD}$ Thesis, Université Mentouri Constantine, 2007 (in French.

[34] NF EN 13263-1+A1 Fumée de silice pour béton. Partie 1: définition, exigences et critères de conformité, 2009 (in French).

[35] W.A. Gutteridge, J.A. Dalziel, Filler cement: The effect of the secondary component on the hydration of Portland cement: Part I. A fine non-hydraulic filler, Cem. Concr. Res. 20 (1990) 778-782. doi:http://dx.doi.org/10.1016/0008-8846(90)90011-L.

[36] K. Scrivener, W. Wieker, Advances in hydration at low, ambient and elevated temperatures, in: 9th Int. Congr. Chem. Cem., 1992: pp. 1449-1482. 
552

553

554

555

556

557

558

559

560

561

562

563

564

565

566

567

568

569

570

571

572

573

574

575

576

577

578

579

580

581

582

583

584

585

586

587

588

589

590

591

592

593

594

595

596

[37] R. Talero, C. Pedrajas, M. González, C. Aramburo, A. Blázquez, V. Rahhal, Role of the filler on Portland cement hydration at very early ages: Rheological behaviour of their fresh cement pastes, Constr. Build. Mater. 151 (2017) 939-949. doi:https://doi.org/10.1016/j.conbuildmat.2017.06.006.

[38] P. Lawrence, M. Cyr, E. Ringot, Mineral admixtures in mortars: Effet of type, amount and fineness of fine constituent on compressive strength, Cem. Concr. Res. 35 (2005) 10921105.

[39] V. Waller, Relation entre composition des bétons, exothermie en cours de prise et résistance en compression, PhD Thesis, Ecole Nationale des Ponts et Chaussées, 1999 (in French).

[40] F. Han, X. He, Z. Zhang, J. Liu, Hydration heat of slag or fly ash in the composite binder at different temperatures, Thermochim. Acta. 655 (2017) 202-210. doi:http://dx.doi.org/10.1016/j.tca.2017.07.002.

[41] B. Klemczak, M. Batog, Heat of hydration of low-clinker cements, J. Therm. Anal. Calorim. 123 (2016) 1351-1360. doi:10.1007/s10973-015-4782-y.

[42] V. Kocaba, Development and evaluation of methods to follow microstructural development of cementitious systems including slags, $\mathrm{PhD}$ Thesis, Ecole polytechnique fédérale de Lausanne, 2009.

[43] S. Schindler, K.J. Folliard, Heat of hydration models for cementitious materials, ACI Mater. J. 102 (2005) 24-33.

[44] S. Arrhénius, Quantitative laws in biological chemistry, G. Bell and Sons Ed., London, 1915.

[45] G.J. Verbeck, Chemistry of hydration of Portland cement - III. Energetics of the hydration of Portland cement, in: 4th Int. Symp. Chem. Cem., 1960: pp. 1453-1465.

[46] A.K. Schindler, Effect of temperature on hydration of cementitious materials, Mater. J. 101 (2004) 72-81.

[47] L. D'Aloia, G. Chanvillard, Determining the "apparent" activation energy of concrete: Eanumerical simulations of the heat of hydration of cement, Cem. Concr. Res. 32 (2002) 1277-1289. doi:http://dx.doi.org/10.1016/S0008-8846(02)00791-3.

[48] M. Maage, Strength and heat development in concrete: influence of fly ash and condensed silica fume, in: 2nd CANMETACI Int. Conf. Fly Ash Silica Fume Slag Nat. Pozzolans Concr., 1986.

[49] M. Cyr, P. Lawrence, E. Ringot, A. Carles-Gibergues, Variability of efficiency factors characterising mineral admixtures, Mater. Struct. 33 (2000) 466. doi:10.1007/bf02480667.

[50] M.I.A. Khokhar, E. Roziere, P. Turcry, F. Grondin, A. Loukili, Mix design of concrete with high content of mineral additions: Optimisation to improve early age strength, Cem. Concr. Compos. 32 (2010) 377-385. doi:http://doi.org/10.1016/j.cemconcomp.2010.01.006.

[51] J. Hu, Z. Ge, K. Wang, Influence of cement fineness and water-to-cement ratio on mortar early-age heat of hydration and set times, Constr. Build. Mater. 50 (2014) 657-663. doi:http://dx.doi.org/10.1016/j.conbuildmat.2013.10.011.

[52] J.M. Torrenti, F. Benboudjema, Mechanical threshold of cimentitious materials at early age, Mater. Struct. 38 (2005) 299-304.

[53] L. Stefan, Étude expérimentale et modélisation de l'évolution des propriétés mécaniques au jeune âge dans les matériaux cimentaires, PhD Thesis, Ecole Normale Supérieure de Cachan et Université de Laval, 2009 (in French).

[54] P.C. Hewlett, Lea's Chemistry of Cement and Concrete, 4th Edition, Elsevier, 1998. 
597

598

599

600

601

602

603

604

605

606

607

608

609

610

611

612

613

614

615

616

617

618

619

620

621

622

623

624

625

626

627

628

629

630

631

632

633

634

635

636

637

638

639

640

[55] E.-H. Kadri, R. Duval, Hydration heat kinetics of concrete with silica fume, Constr. Build. Mater. 23 (2009) 3388-3392. doi:https://doi.org/10.1016/j.conbuildmat.2009.06.008.

[56] N. Hani, O. Nawawy, K.S. Ragab, M. Kohail, The effect of different water/binder ratio and nano-silica dosage on the fresh and hardened properties of self-compacting concrete, Constr. Build. Mater. 165 (2018) 504-513. doi:https://doi.org/10.1016/j.conbuildmat.2018.01.045.

[57] M.B. Bizinotto, F. Faleschini, C.G.J. Fernández, D.F.A. Hernández, Effects of chemical admixtures on the rheology of fresh recycled aggregate concretes, Constr. Build. Mater. 151 (2017) 353-362. doi:https://doi.org/10.1016/j.conbuildmat.2017.06.111.

[58] E.H. Kadri, Contribution à l'étude de l'influence de la fumée de silice sur les caractéristiques des bétons à hautes performances, $\mathrm{PhD}$ Thesis, Université de Cergy Pontoise, 1998 (in French).

[59] H. Huang, C. Qian, F. Zhao, J. Qu, J. Guo, M. Danzinger, Improvement on microstructure of concrete by polycarboxylate superplasticizer (PCE) and its influence on durability of concrete, Constr. $\quad$ Build. Mater. $110 \quad$ (2016) 293-299. doi:https://doi.org/10.1016/j.conbuildmat.2016.02.041.

[60] F. Huang, H. Li, Z. Yi, Z. Wang, Y. Xie, The rheological properties of self-compacting concrete containing superplasticizer and air-entraining agent, Constr. Build. Mater. 166 (2018) 833-838. doi:https://doi.org/10.1016/j.conbuildmat.2018.01.169.

[61] A. Mardani-Aghabaglou, O.C. Boyaci, H. Hosseinnezhad, B. Felekoglu, K. Ramyar, Effect of gypsum type on properties of cementitious materials containing high range water reducing admixture, Cem. Concr. Compos. 68 (2016) 15-26.

[62] EN 934-2 Admixtures for concrete, mortar and grout - Part 2 : concrete admixtures Definitions, requirements, conformity, marking and labelling, 2012.

[63] NF EN 196-3+A1 Méthodes d'essais des ciments. Partie 3 : détermination du temps de prise et de la stabilité, 2009 (in French).

[64] EN 196-9 Methods of testing cement - Part 9 : heat of hydration - Semi-adiabatic method, 2010.

[65] EN 196-1 Methods of testing cement - Part 1 : determination of strength, 2016.

[66] NF EN 15167-1 Laitier granulé de haut-fourneau moulu pour utilisation dans le béton, mortier et coulis. Partie 1 : définitions, exigences et critères de conformité, 2006 (in French).

[67] NF EN 450-1 Cendres volantes pour béton Partie 1 : Définition, spécification et critères de conformité, 2012 (in French).

[68] EN 12350-2 Testing fresh concrete - Part 2 : slump test, 2012.

[69] EN 12390-14 Testing hardened concrete - Part 14 : semi-adiabatic method for the determination of heat released by concrete during its hardening process, 2018.

[70] EN 12390-3 Testing hardened concrete - Part 3: compressive strength of test specimens, 2012.

[71] A. Pertué, Etude expérimentale du retrait endogène, du fluage propre et de la fissuration des matrices cimentaires aux jeune et très jeune âges, Thesis, Thèse de l'Université de Nantes, 2008.

[72] A. Bourchy, Relation chaleur d'hydratation du ciment - montée en température et contraintes générées au jeune âge du béton, $\mathrm{PhD}$ thesis, Université Paris-Est, 2018 (in French) 
641 Appendix A. Concretes name and formulation.

\begin{tabular}{|c|c|c|c|c|c|}
\hline & \multicolumn{5}{|c|}{ Factors } \\
\hline Concrete name & $\begin{array}{c}\text { Cement } \\
\text { type }\end{array}$ & $\mathrm{A} / \mathrm{B}$ & Addition & $\mathrm{W} / \mathrm{B}$ & $\begin{array}{l}\text { Chemical } \\
\text { admixture }\end{array}$ \\
\hline C1_25S_0.375_0.45 & $\mathrm{C} 1$ & 25 & $S$ & 0.375 & 0.45 \\
\hline C1_25S_0.4_0.38 & C3 & 25 & $S$ & 0.4 & 0.38 \\
\hline C1_25S_0.425_0.52 & $\mathrm{C} 2$ & 25 & $\mathrm{~S}$ & 0.425 & 0.52 \\
\hline C1_50S_0.425_0.38 & $\mathrm{C} 1$ & 50 & $S$ & 0.425 & 0.38 \\
\hline C1_250S_0.375_0.52 & C3 & 50 & $S$ & 0.375 & 0.52 \\
\hline C1_50S_0.4_0.45 & $\mathrm{C} 2$ & 50 & $\mathrm{~S}$ & 0.4 & 0.45 \\
\hline C1_75S_0.4_0.52 & $\mathrm{C} 1$ & 75 & $\mathrm{~S}$ & 0.4 & 0.52 \\
\hline C1_75S_0.425_0.45 & $\mathrm{C} 3$ & 75 & $\mathrm{~S}$ & 0.425 & 0.45 \\
\hline C1_75S_0.375_0.38 & $\mathrm{C} 2$ & 75 & $\mathrm{~S}$ & 0.375 & 0.38 \\
\hline C1_12.5FA_0.375_0.60 & $\mathrm{C} 1$ & 12.5 & FA & 0.375 & 0.60 \\
\hline C1_12.5FA_0.4_0.51 & $\mathrm{C} 3$ & 12.5 & FA & 0.4 & 0.51 \\
\hline C1_12.5FA_0.425_0.69 & $\mathrm{C} 2$ & 12.5 & FA & 0.425 & 0.69 \\
\hline C1_25FA_0.425_0.51 & $\mathrm{C} 1$ & 25 & FA & 0.425 & 0.51 \\
\hline C1_25FA_0.375_0.69 & $\mathrm{C} 3$ & 25 & FA & 0.375 & 0.69 \\
\hline C1_25FA_0.4_0.60 & $\mathrm{C} 2$ & 25 & FA & 0.4 & 0.60 \\
\hline C1_37.5FA_0.4_0.69 & $\mathrm{C} 1$ & 37.5 & FA & 0.4 & 0.69 \\
\hline C1_37.5FA_0.425_0.60 & C3 & 37.5 & FA & 0.425 & 0.60 \\
\hline C1_37.5FA_0.375_0.51 & $\mathrm{C} 2$ & 37.5 & FA & 0.375 & 0.51 \\
\hline C1_4SF_0.375_1.00 & $\mathrm{C} 1$ & 4 & SF & 0.375 & 1.00 \\
\hline C1_4SF_0.4_0.85 & $\mathrm{C} 3$ & 4 & SF & 0.4 & 0.85 \\
\hline C1_4SF_0.425_1.15 & $\mathrm{C} 2$ & 4 & SF & 0.425 & 1.15 \\
\hline C1_8SF_0.425_0.85 & $\mathrm{C} 1$ & 8 & SF & 0.425 & 0.85 \\
\hline C1_8SF_0.375_1.15 & $\mathrm{C} 3$ & 8 & SF & 0.375 & 1.15 \\
\hline C1_8SF_0.4_1.00 & $\mathrm{C} 2$ & 8 & SF & 0.4 & 1.00 \\
\hline C1_12SF_0.4_1.15 & $\mathrm{C} 1$ & 12 & $\mathrm{SF}$ & 0.4 & 1.15 \\
\hline C1_12SF_0.425_1.00 & C3 & 12 & SF & 0.425 & 1.00 \\
\hline C1_12SF_0.375_0.85 & $\mathrm{C} 2$ & 12 & SF & 0.375 & 0.85 \\
\hline C1_0.4_0.6 & $\mathrm{C} 1$ & - & - & 0.4 & 0.6 \\
\hline C1_0.4_0.9 & $\mathrm{C} 2$ & - & - & 0.4 & 0.9 \\
\hline C1_0.4_0.6Tempo10 & $\mathrm{C} 3$ & - & - & 0.4 & 0.6 with Tempo 10 \\
\hline
\end{tabular}

